\title{
Prevalence of ADHD Symptoms among a Sample of Egyptian School Age Children
}

\author{
REDA EL-SAYED, M.Sc.*; MAHMOUD EL-MOGY, M.D.*; HASSAN ALI, M.D.* and \\ MOHAMED M.A. GHOWINAM, M.D.** \\ The Departments of Pediatrics* and Psychiatry Medicine**, Faculty of Medicine, Al-Azhar University, Cairo, Egypt
}

\begin{abstract}
Background: Attention Deficit Hyperactivity Disorder (ADHD) is highly prevalent in school age children worldwide.

Objective: This study was undertaken to assess the prevalence and association of ADHD with child demographics among a sample of Egyptian school age children.

Patients and Methods: 111 children admitted to the outpatient pediatric clinic in Al-Azhar University hospitals were evaluated using Psychiatric interview-IQ and Conner's Abbreviated Rating Scale that consists of several behavioral parameters for the diagnosis of ADHD.

Results: The most prevalent disorder in this study was learning disorder $(23.1 \%)$ followed by ADHD (20.9\%) and impulsive-hyperactive disorder (14.1\%). The ADHD showed a positive correlation with conduct disorder, learning problem, psychosomatic disorder, impulsive-hyperactive disorder, and anxiety disorder. Male gender and consanguinity were significantly correlated with higher incidence of ADHD.

Conclusion: The most prevalent disorder in this study was learning disorder (23.1\%) followed by ADHD (20.9\%). ADHD was significantly correlated with other types of emotional and behavioral disorders. Also, male gender and consanguinity were a significant predictors for ADHD.
\end{abstract}

Key Words: Prevalence-ADHD-Male gender-Behavioral disorders - Emotional disorders.

\section{Introduction}

ATTENTION-DEFICIT hyperactivity disorder (ADHD) is a neurobehavioral disorder that typically begins in childhood and often persists into adulthood. ADHD is characterized by developmentally inappropriate levels of attention and hyperactivity resulting in functional impairment in academic, family, and social settings [1,2].

ADHD is a clinically heterogeneous condition, in which symptoms overlap or occur with other

Correspondence to: Dr. Reda El-Sayed, E-Mail: redamohamed24@yahoo.com. conditions. ADHD is most often identified when children first start school [3]. However, its symptoms may persist and continue to cause impairment throughout adolescence and adulthood [4]

ADHD may also be identified in children of preschool age [5]. The worldwide prevalence of ADHD ranges from $5.29 \%$ to $7.1 \%$ (5.4-8.7\% in Africa, $6.24 \%$ in Jordan, $16.4 \%$ in Saudi Arabia) $[4,6]$. The etiology of ADHD is not clearly understood; there is a growing body of evidence for the involvement of genetic, neurobiological and environmental factors [7-10]. A range of environmental factors have been implicated in the etiology of ADHD including risk factors during pregnancy or early childhood, social risk factors, and geneenvironment interactions [11,12]

The aim of this study was to assess the prevalence of behavioral and emotional symptoms among a sample of Egyptian school age children.

\section{Patients and Methods}

After ethical approval from Ethical Committee of Al-Azhar University Hospitals and written approval from the families of children who were allocated in the study. The study population in this prospective study were 277 children admitted to the Outpatient Pediatric Clinic in Al-Azhar University Hospitals (SAYED GALAL hospital from March 2016 to September 2016). The inclusion criteria were both sex school age children (6-12) with one of parent's alive. Children suffering from severe acute disease as pneumonia, chronic diseases as cardiac or hepatic, history of convulsion or CNS affection, established hereditary syndromes as Down as well as established epileptic child were excluded from the study. 
Tools:

- Clinical history taking and clinical examination of chest-cardiac-neuro.

- Conner's Abbreviated Rating Scale (CARS): This is a rating scale that consists of several behavioral parameters for the diagnosis of ADHD. This was rated by the parents and the teachers.

- Psychiatric interview-IQ.

Statistical analysis of data was done using IBMC SPSS $@$ Statistics version 22 (IBM@) Corp., Armonk, NY, USA). Numerical data were expressed as mean and standard deviation. Qualitative data were expressed as frequency and percentage. Chi-square test (Fisher's exact test) was used to examine the relation between qualitative variables. For quantitative data, comparison between two groups was done using independent sample $t$-test. All tests were two-tailed. A $p$-value $<0.05$ was considered significant.

\section{Results}

The mean age of included subjects was 8,6 , the mean age of the fathers of included children was 41.3 years old, and the mother's age was 36.5 years old (Table 1). Most of the children were male (57\%) and $43 \%$ were females. About $90.6 \%$ of children had no consanguinity having mental dis- orders and only $9.4 \%$ had relatives having mental disorders. The most of children $(96 \%)$ use their right hand and only $4 \%$ use their left hand. The majority of children $(43 \%)$ were the first children, $40.8 \%$ were the 2 nd in order and $16.2 \%$ of them were the last (Table 2).

The most prevalent disorder in this study was learning disorder (23.1\%) followed by ADHD (20.9\% and impulsive-hyperactive disorder (14.1\%). The least incidence disorders were conduct disorder $(7.9 \%)$, anxiety disorder $(6.9 \%)$ and psychosomatic disorder (5.4\%) (Table 3$)$.

The ADHD showed a positive correlation with conduct disorder, learning problem, psychosomatic disorder, impulsive-hyperactive disorder, and anxiety disorder (Table 4).

Male gender was significantly correlated with ADHD ( $p$-value=0.039). Consanguinity showed a highly significant correlation with the higher incidence of ADHD. However, the type of used hand and order of child in family showed no significant correlation with ADHD. Also, the age of mother, father and child showed no significant correlation with ADHD (Table 5). But, ADHD symptoms were higher during the age from 6-8 years old than the age from 9-12 years old (Table 6 \& Fig. 1).

Table (1): Age of included subjects and family.

Table (2): Demographics of the included children.

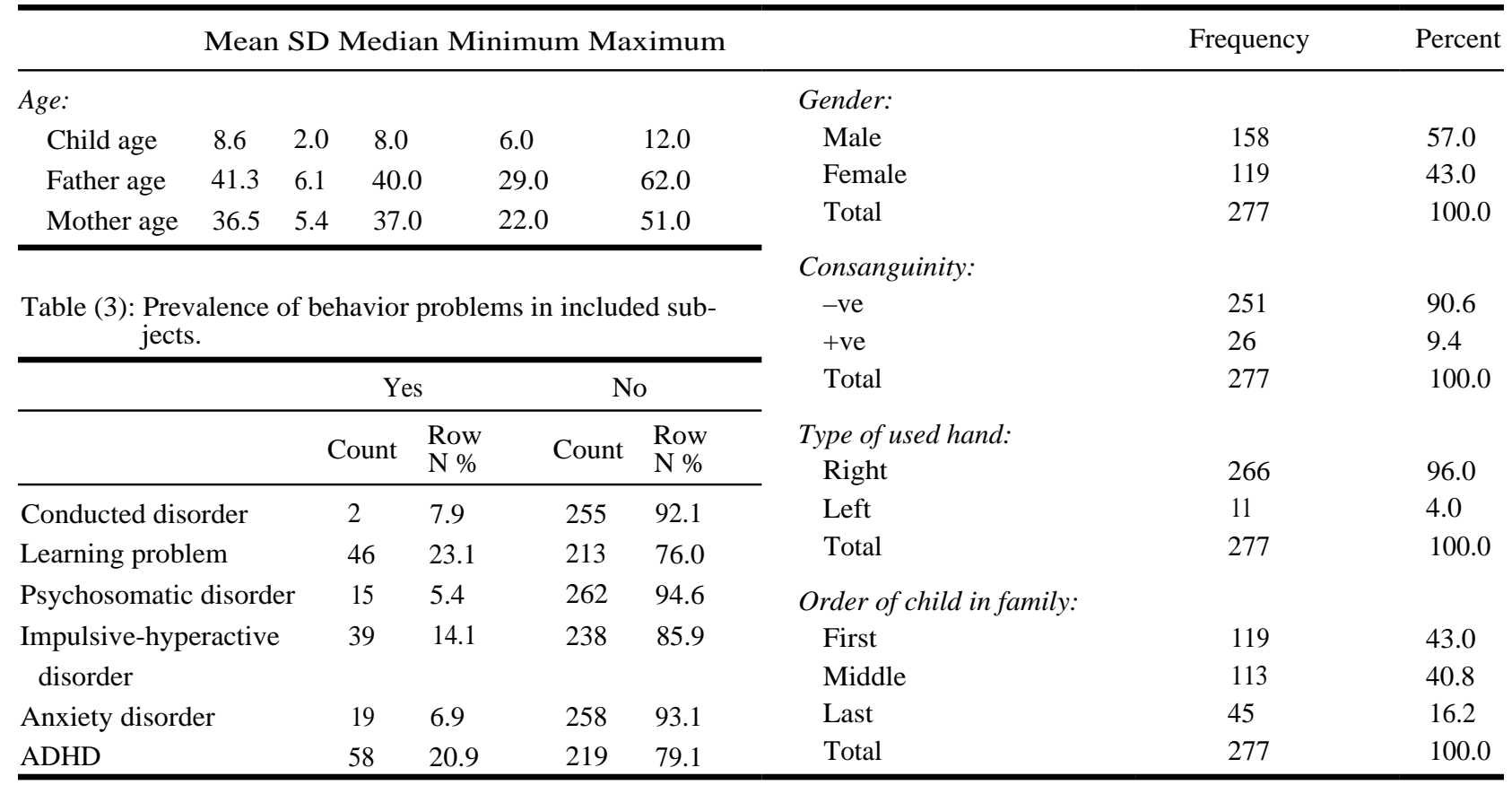


Table (4): Correlations between ADHD and other diagnosed disorder.

\begin{tabular}{|c|c|c|c|c|c|c|}
\hline \multirow{2}{*}{ Crosstab } & & & \multicolumn{2}{|c|}{ ADHD } & \multirow{2}{*}{ Total } & \multirow{2}{*}{ Fisher's exact test } \\
\hline & & & Yes & No & & \\
\hline \multirow[t]{2}{*}{ Conducted disorder } & Yes & $\begin{array}{l}\text { Count } \\
\% \text { within ADHD }\end{array}$ & $\begin{array}{l}18 \\
31.0 \%\end{array}$ & $\begin{array}{l}4 \\
1.8 \%\end{array}$ & $\begin{array}{l}22 \\
7.9 \%\end{array}$ & $\begin{array}{l}\text { Value }=59.057 \\
p \text {-value }=0.000\end{array}$ \\
\hline & No & $\begin{array}{l}\text { Count } \\
\% \text { within ADHD }\end{array}$ & $\begin{array}{l}40 \\
69.0 \%\end{array}$ & $\begin{array}{l}215 \\
98.2 \%\end{array}$ & $\begin{array}{l}255 \\
92.1 \%\end{array}$ & \\
\hline \multirow[t]{2}{*}{ Learning problem } & Yes & $\begin{array}{l}\text { Count } \\
\% \text { within ADHD }\end{array}$ & $\begin{array}{l}43 \\
74.1 \%\end{array}$ & $\begin{array}{l}21 \\
9.6 \%\end{array}$ & $\begin{array}{l}64 \\
23.1 \%\end{array}$ & $\begin{array}{l}\text { Value }=123.675 \\
p \text {-value }=0.000\end{array}$ \\
\hline & No & $\begin{array}{l}\text { Count } \\
\% \text { within ADHD }\end{array}$ & $\begin{array}{l}15 \\
25.9 \%\end{array}$ & $\begin{array}{l}198 \\
90.4 \%\end{array}$ & $\begin{array}{l}213 \\
76.9 \%\end{array}$ & \\
\hline \multirow[t]{2}{*}{ Pshychosomatic disorder } & Yes & $\begin{array}{l}\text { Count } \\
\% \text { within ADHD }\end{array}$ & $\begin{array}{l}10 \\
17.2 \%\end{array}$ & $\begin{array}{l}5 \\
2.3 \%\end{array}$ & $\begin{array}{l}15 \\
5.4 \%\end{array}$ & $\begin{array}{l}\text { Value }=22.734 \\
p \text {-value }=0.000\end{array}$ \\
\hline & No & $\begin{array}{l}\text { Count } \\
\% \text { within ADHD }\end{array}$ & $\begin{array}{l}48 \\
82.8 \%\end{array}$ & $\begin{array}{l}214 \\
97.7 \%\end{array}$ & $\begin{array}{l}262 \\
94.6 \%\end{array}$ & \\
\hline \multirow[t]{2}{*}{ Impulsive-hyperactive disorder } & Yes & $\begin{array}{l}\text { Count } \\
\% \text { within ADHD }\end{array}$ & $\begin{array}{l}29 \\
50.0 \%\end{array}$ & $\begin{array}{l}10 \\
4.6 \%\end{array}$ & $\begin{array}{l}39 \\
14.1 \%\end{array}$ & $\begin{array}{l}\text { Value }=91.628 \\
p \text {-value }=0.000\end{array}$ \\
\hline & No & $\begin{array}{l}\text { Count } \\
\% \text { within ADHD }\end{array}$ & $\begin{array}{l}29 \\
50.0 \%\end{array}$ & $\begin{array}{l}209 \\
95.4 \%\end{array}$ & $\begin{array}{l}238 \\
85.9 \%\end{array}$ & \\
\hline \multirow[t]{2}{*}{ Anxiety disorder } & Yes & $\begin{array}{l}\text { Count } \\
\% \text { within ADHD }\end{array}$ & $\begin{array}{l}7 \\
12.1 \%\end{array}$ & $\begin{array}{l}12 \\
5.5 \%\end{array}$ & $\begin{array}{l}19 \\
6.9\end{array}$ & $\begin{array}{l}\text { Value }=8.526 \\
p \text {-value }=0.048\end{array}$ \\
\hline & No & $\begin{array}{l}\text { Count } \\
\% \text { within ADHD }\end{array}$ & $\begin{array}{l}51 \\
87.9 \%\end{array}$ & $\begin{array}{l}207 \\
94.5 \%\end{array}$ & $\begin{array}{l}258 \\
93.1 \%\end{array}$ & \\
\hline
\end{tabular}

Table (5): Correlations between ADHD and child demographics.

\begin{tabular}{|c|c|c|c|c|c|c|}
\hline & & & \multicolumn{2}{|c|}{ ADHD } & \multirow{2}{*}{ Total } & \multirow{2}{*}{ Pearson Chi-Square } \\
\hline & & & Yes & No & & \\
\hline \multirow[t]{2}{*}{ Gender } & Male & $\begin{array}{l}\text { Count } \\
\% \text { within Sex }\end{array}$ & 40 & 118 & 158 & \multirow{2}{*}{$\begin{array}{l}\text { Value }=4.258 \\
p \text {-value }=0.039\end{array}$} \\
\hline & Female & $\begin{array}{l}\text { Count } \\
\% \text { within Sex }\end{array}$ & $\begin{array}{l}18 \\
15.1 \%\end{array}$ & $\begin{array}{l}101 \\
84.9 \%\end{array}$ & $\begin{array}{l}119 \\
100.0 \%\end{array}$ & \\
\hline \multirow[t]{2}{*}{ Cons. } & -ve & $\begin{array}{l}\text { Count } \\
\% \text { within Cons. }\end{array}$ & $\begin{array}{l}44 \\
17.5 \%\end{array}$ & $\begin{array}{l}207 \\
82.5 \%\end{array}$ & $\begin{array}{l}251 \\
100.0 \%\end{array}$ & \multirow[t]{2}{*}{$\begin{array}{l}\text { Value }=18.770 \\
p \text {-value }=0.000\end{array}$} \\
\hline & $+\mathrm{ve}$ & $\begin{array}{l}\text { Count } \\
\% \text { within Cons. }\end{array}$ & $\begin{array}{l}14 \\
53.8 \%\end{array}$ & $\begin{array}{l}12 \\
46.2 \%\end{array}$ & $\begin{array}{l}26 \\
100.0 \%\end{array}$ & \\
\hline \multirow[t]{2}{*}{ Hand } & Right & $\begin{array}{l}\text { Count } \\
\% \text { within Hand }\end{array}$ & $\begin{array}{l}54 \\
20.3 \%\end{array}$ & $\begin{array}{l}212 \\
79.7 \%\end{array}$ & $\begin{array}{l}266 \\
100.0 \%\end{array}$ & \multirow[t]{2}{*}{$\begin{array}{l}\text { Value }=1.646 \\
p \text {-value }=0.250\end{array}$} \\
\hline & Left & $\begin{array}{l}\text { Count } \\
\% \text { within Hand }\end{array}$ & $\begin{array}{l}4 \\
36.4 \%\end{array}$ & $\begin{array}{l}7 \\
63.6 \%\end{array}$ & $\begin{array}{l}11 \\
100.0 \%\end{array}$ & \\
\hline \multirow[t]{4}{*}{ Order } & First & $\begin{array}{l}\text { Count } \\
\% \text { within Order }\end{array}$ & $\begin{array}{l}28 \\
23.5 \%\end{array}$ & $76.5 \%$ & $\begin{array}{l}119 \\
100.0 \%\end{array}$ & \multirow[t]{3}{*}{$\begin{array}{l}\text { Value }=3.087 \\
p \text {-value }=0.214\end{array}$} \\
\hline & Middle & $\begin{array}{l}\text { Count } \\
\% \text { within Order }\end{array}$ & $\begin{array}{l}18 \\
19.5 \%\end{array}$ & $\begin{array}{l}95 \\
84.1 \%\end{array}$ & $\begin{array}{l}113 \\
100.0 \%\end{array}$ & \\
\hline & Last & $\begin{array}{l}\text { Count } \\
\% \text { within Order }\end{array}$ & $\begin{array}{l}12 \\
26.7 \%\end{array}$ & $\begin{array}{l}33 \\
73.3 \%\end{array}$ & $\begin{array}{l}45 \\
100.0 \%\end{array}$ & \\
\hline & & Mean & Std. deviation & Mean & Std. deviation & Independent samples test \\
\hline Age & $\begin{array}{l}\text { Age } \\
\text { Father a } \\
\text { Mother }\end{array}$ & $\begin{array}{l}8.4 \\
40.2 \\
35.7\end{array}$ & $\begin{array}{l}2.0 \\
6.4 \\
5.9\end{array}$ & $\begin{array}{l}8.6 \\
41.5 \\
36.7\end{array}$ & $\begin{array}{l}2.0 \\
6.1 \\
5.2\end{array}$ & $\begin{array}{l}p \text {-value }=0.348 \\
p \text {-value }=0.142 \\
p \text {-value }=0.214\end{array}$ \\
\hline
\end{tabular}


Table (6): Prevalence of ADHD symptoms in different age.

\begin{tabular}{|c|c|c|c|c|c|c|}
\hline & & & \multicolumn{4}{|c|}{ ADHD symptoms } \\
\hline & & & Yes & No & Border line & Total \\
\hline \multirow{4}{*}{ Age } & $6-8 y$ & Count & 41 & 127 & 12 & 180 \\
\hline & & Row N \% & $22.8 \%$ & $70.6 \%$ & $6.7 \%$ & $100.0 \%$ \\
\hline & $9-12 y$ & Count & 17 & 78 & 2 & 97 \\
\hline & & Row N \% & $17.5 \%$ & $80.4 \%$ & $2.1 \%$ & $100.0 \%$ \\
\hline
\end{tabular}

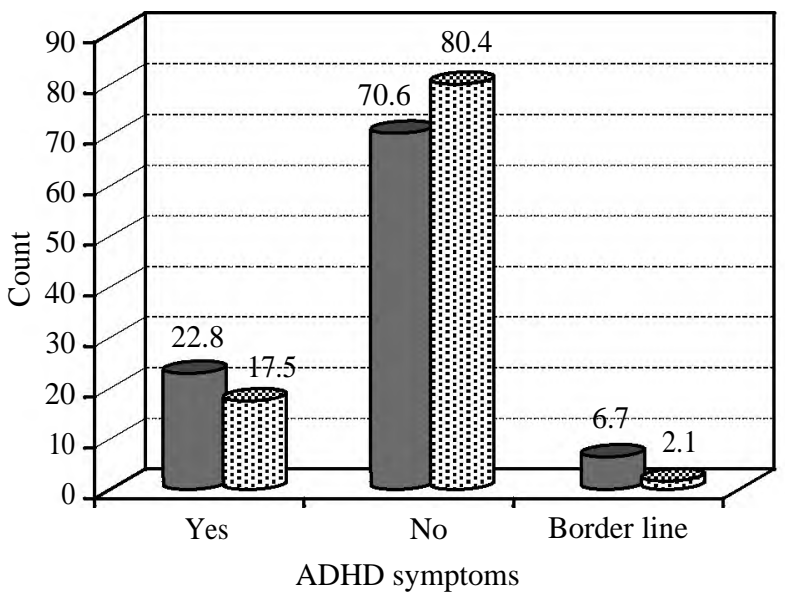

\section{Age 6-8y Age 9-12y}

Fig. (1): Prevalence of ADHD symptoms in different age.

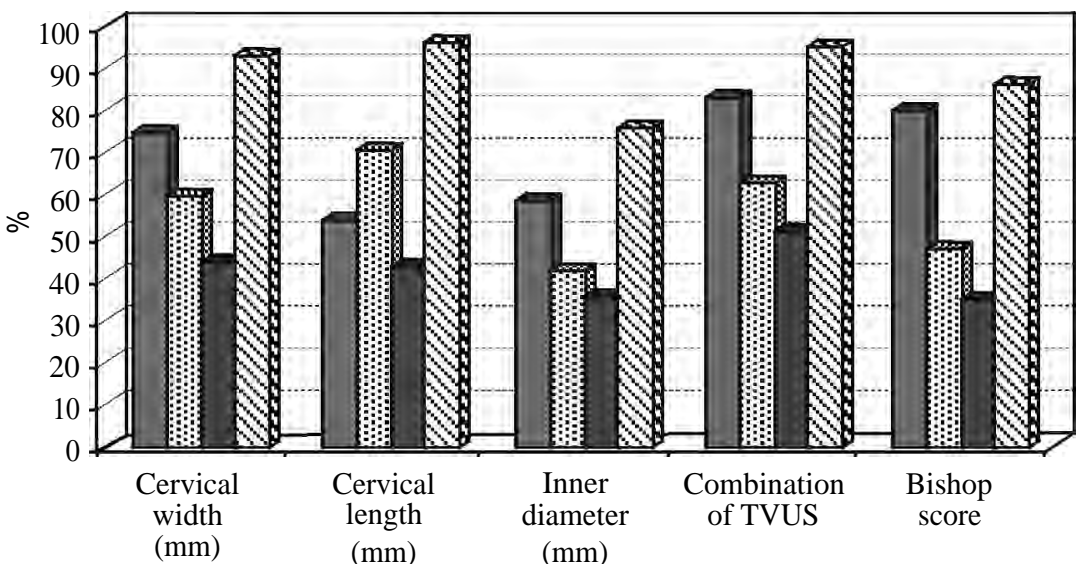

Discussion

Attention Deficit Hyperactivity Disorder (ADHD) is highly prevalent in children worldwide and its prevalence in adults is increasingly recognized [13]. In the present study, the most prevalent disorder was learning disorder $(23.1 \%)$ followed by ADHD (20.9\% and impulsive-hyperactive disorder $(14.1 \%)$. The least incidence disorders were conduct disorder (7.9\%), anxiety disorder (6.9\%) and psychosomatic disorder (5.4\%).

In consistence, ADHD prevalence in Fayoum City was $20.5 \%$, however, was the highest in comparison with the DSM-5 both internationally and in the Arab countries [14]. However, The DSM-5 showed that the prevalence of ADHD was approximately $5 \%$ in most cultures $[15,16]$.
Contrast studies showed that the prevalence of ADHD based on the DSM-IV criteria was found to be $6.9 \%$ among primary school children of Menoufia governorate, Egypt [1] which is higher than the results of another study (5.1\%) done in the same governorate in 2007 [17]. Also, another study done in Assuit city, Egypt showed that the prevalence of ADHD was 6\% [18]. In addition, the results in Suez Canal University Hospital by Magda et al., which found the prevalence to be $13.6 \%$ [19]

As for learning difficulties and in the same respect with our results, the rate of incidence of difficulties related to learning lie between 12 per cent and 30 per cent of the school population [20,21]

The prevalence of hyperactive disorder in the present study was higher than another study con- 
ducted in Primary School Students in Jeddah city, KSA and the prevalence of impulsive hyperactive disorder was $2.2 \%$ [22]. In consistence, a study conducted among Male Primary School Children in Dammam, Saudi Arabia [23] showed that the prevalence of hyperactivity-impulsivity was 12.4 which is close to our results.

The results for conduct disorder in this study were lower than other studies as in several studies reported the prevalence of conduct disorder in different Middle Eastern countries; for instance, Mohammadi et al., revealed a prevalence rate of $32.9 \%$ for conduct disorder in Iranian children and adolescents [24]. Another research which was conducted on 6-12-year-old children in Egypt reported the prevalence of conduct disorder to be $25.3 \%$

The median prevalence rate of all anxiety disorders in a recent review was $8 \%$ with an extremely wide range of estimates (e.g., $2 \%$ to $24 \%$ ) which is approximately like these present results (6.9\%) [26]Also, the positive cases in an Egyptian Sample of School Students at the Age of 12-18 Years according to both GHQ and Anxiety scale represented $25.5 \%$ of total investigated cases completing the study [27].

This study showed that ADHD showed a positive correlation with conduct disorder, learning problem, psychosomatic disorder, impulsivehyperactive disorder, and anxiety disorder. In accordance with our results, conduct disorder was significantly associated with ADHD in school age children [28,29], Although a number of studies have examined the coexistence of learning disorders and ADHD, only a few have studied the prevalence of ADHD in a cohort of school-aged children diagnosed with learning problems [30,31]. In addition, ADHD patients show elevated levels of impulsivity as measured by a variety of tasks [32] Moreover, the anxiety disorders have been found to occur more commonly in the ADHD population $[33,34]$

Male gender was significantly correlated with ADHD $(p$-value $=0.039)$. Consanguinity showed a highly significant correlation with the higher incidence of ADHD. However, the type of used hand and order of child in family showed no significant correlation with ADHD. Also, the age of mother, father and child showed no significant correlation with ADHD.

In accordance, some studies revealed that males had a higher prevalence of ADHD than females and had about three folds increased chance of having ADHD (1). This was in concordance with several studies that showed a well-documented gender difference in the prevalence of ADHD $[1,14,22,35]$

Regarding to the order of child in the family, in contrast results revealed that the larger the family size, the higher the prevalence of ADHD [1]. Large family size is contributing factor to ADHD due to impact on interpersonal relationships between family members $[36,37]$

As for Consanguinity and in accordance with our study, a current study demonstrated that consanguinity had about one and half folds increased chance to lead to ADHD (adjusted OR=1.4) [1] which was in concordance with Jordanian study which found that the prevalence of ADHD was $34.8 \%$ among consanguineous families and the inattentive subtype was more common than others [37]. Another study in Qatar showed a significant relationship between ADHD symptoms and consanguineous parents [38]

In agreement with our results, a recent study in Fayoum City (Egypt) Among School-Age Children showed that there was non-significant correlation between age and ADHD prevalence [14]

\section{Conclusion and Recommendations:}

The presently prospective study showed that the most prevalent disorder was learning disorder (23.1\%) followed by ADHD (20.9\%). ADHD was significantly correlated with other types of emotional and behavioral disorders. Also, male gender and consanguinity were a significant predictors for ADHD. Further evaluation of the accurate prevalence and correlations of ADHD with child demographics and efficiency should be studied in large population studies.

Ethics: This study was approved from the Ethical Committee of Al-Hussein University Hospital, and a written informed consent was obtained from subjects included in the study.

Funding: We ensure and stated that our study is self-funded by authors without any governmental or institutional support.

Disclosures: We declare that we have no conflicts of interest.

\section{References}

1- FARAHAT T., ALKOT M., RAJAB A. and ANBAR R.: Attention-Deficit Hyperactive Disorder among Primary School Children in Menoufia Governorate, Egypt. International Journal of Family Medicine, 2014: 257369, 2014. 
2- POLANCZYK G.V., SALUM G.A., SUGAYA L.S., CAYE A. and ROHDE L.A.: Annual research review: A meta-analysis of the worldwide prevalence of mental disorders in children and adolescents. Journal of child psychology and psychiatry, and Allied Disciplines, 56 (3): 345-65, 2015.

3- MARTIN A.B., LASSMAN D., WASHINGTON B., CATLIN A. and TEAM N.H.E.A.: Growth in US health spending remained slow in 2010; health share of gross domestic product was unchanged from 2009. Health Affairs. 3I (1): 208-19, 2012.

4- WILLCUTT E.G.: The prevalence of DSM-IV attentiondeficit/hyperactivity disorder: A meta-analytic review. Neurotherapeutics: The journal of the American Society for Experimental. Neuro. Therapeutics., 9 (3): 490-9, 2012.

5- SCHLACK R., HOLLING H., KURTH B.M. and HUSS M.: [The prevalence of attention-deficit/hype ractivity disorder (ADHD) among children and adolescents in Germany. Initial results from the German Health Interview and Examination Survey for Children and Adolescents (KiGGS)]. Bundesgesundheitsblatt, Gesundheitsforschung, Gesundheitsschutz, 50 (5-6): 827-35, 2007.

6- POLANCZYK G., de LIMA M.S., HORTA B.L., BIEDERMAN J. and ROHDE L.A.: The worldwide prevalence of ADHD: A systematic review and metaregression analysis. Am. J. Psychiatry, 164 (6): 942 8, 2007.

7- NEALE B.M., MEDLAND S., RIPKE S., ANNEY R.J., ASHCRSON P., BUITELAAR J., et al.: Case-control genome-wide association study of attention-deficit/hyperactivity disorder. Journal of the American Academy of Child and Adolescent Psychiatry, 49 (9): 906-20, 2010.

8- SANCHEZ-MORA C., RAMOS-QUIROGA J.A., BOSCH R., CORRALES M., GARCIA-MARTINEZ I., NOGUEIRA M., et al.: Case-control genome-wide association study of persistent attention-deficit hyperactivity disorder identifies FBX033 as a novel susceptibility gene for the disorder. Neuropsychopharmacology: Official publication of the American College of Neuropsychopharmacology, 40 (4): 915-26, 2015.

9- SAGIV S.K., EPSTEIN J.N., BELLINGER D.C. and KORRICK S.A.: Pre- and postnatal risk factors for ADHD inanonclinical pediatric population. Journal of Attention Disorders, 17 (1): 47-57, 2013.

10-SHAW P., MALEK M., WATSON B., SHARP W., EVANS A. and GREENSTEIN D.: Development of cortical surface area and gyrification in attention-deficit/hyperactivity disorder. Biological Psychiatry, 72 (3): 191-7, 2012.

11-RETZ W., FREITAG C.M., RETZ-JUNGINGER P., WENZLER D., SCHNEIDER M., KISSLING C., et al.: A functional serotonin transporter promoter gene polymorphism increases ADHD symptoms in delinquents: Interaction with adverse childhood environment. Psychiatry. Res., 158 (2): 123-31, 2008.

12- SANTOS L.M., QUEIROS F.C., BARRETO M.L. and SANTOS D.N.: Prevalence of behavior problems and associated factors in preschool children from the city of Salvador, state of Bahia, Brazil. Revista brasileira de psiquiatria (Sao Paulo, Brazil : 1999), 38 (1): 46-52, 2016.

13- FARAONE S.V., SERGEANT J., GILLBERG C. and BIEDCRMAN J.: The worldwide prevalence of ADHD: is it an American condition? World Psychiatry, 2 (2): 10413, 2003.

14- ABOUL-ATA M.A. and AMIN F.A.: The Prevalence of ADHD in Fayoum City (Egypt) Among School-Age Children: Depending on a DSM-5-Based Rating Scale. Journal of Attention Disorders, 2015.

15-APA. American Psychiatric Association: Diagnostic criteria and codes. In M. B. First \& M. N. Ward (Eds.), Diagnostic and statistical manual of mental disorders (5th ed., pp. 59-65). Washington, DC, 2013.

16- GOMEZ R. and HAFETZ N.: DSM-IV ADHD: Prevalence based on parent and teacher ratings of Malaysian primary school children. Asian Journal of Psychiatry, 4 (1): 41-4, 2011.

17- BISHRY Z., ELWAN M., RASHED N., Al HAMRAWY L., EL-SAYED S. and EL-BAHY M.: Prevalence of attention deficit hyperactivity disorders in primary school children in Shebin El Kom. Curr. Psychiatry, 15: 54-61, 2008 .

18- EL-TALLAWY H.N., HASSAN W.A., EL-BEHARY A and SHEHATA G.A.: Prevalence of attention deficit hyperactivity disorder among elementary schools children in Assiut City-Egypt. Egyptian Journal of Neurology, Psychiatry and Neurosurgery, 42 (2): 517-26, 2005.

19- MAGDA K., EI-DEFRAWI M., ISMAEL M. and AMAL Z.: Pychiatric morbidity among children $6-12$ years attending pediatric outpatient clinic in Suez Canal University Hospital. Current Psychiatry, 7 (3): 276-90, 2000.

20- WESTWOOD P.: Learning and learning difficulties: Approaches to teaching and assessment: Routledge, 2013.

21- KAVALE K.A.: Discrepancy Models in the Identification of Learning Disability. Executive Summary, 2001.

22- HOMIDI M., OBAIDAT Y. and HAMAIDI D.: Prevalence of attention deficit and hyperactivity disorder among primary school students in Jeddah city, KSA. Life Science Journal, 3: 10, 2013.

23- AL HAMED J.H., TAHA A.Z., SABRA A.A. and BELLA H.: Attention Deficit Hyperactivity Disorder (ADHD) among Male Primary School Children in Dammam, Saudi Arabia: Prevalence and Associated Factors. J. Egypt Public Health Assoc., 83 (3-4): 165-82, 2008.

24- MOHAMMADI M.R., SALMANIAN M., GHANIZADEH A., ALAVI A., MALEK A., FATHZADEH H., et al.: Psychological problems of Iranian children and adolescents: Parent report form of Strengths and Difficulties Questionnaire. Journal of mental health (Abingdon, England), 23 (6): 287-91, 2014.

25- ELHAMID A.A., HOWE A. and READING R.: Prevalence of emotional and behavioural problems among 6-12 year old children in Egypt. Social psychiatry and psychiatric epidemiology, 44 (1): 8-14, 2009.

26- COSTELLO E.J., EGGER H. and ANGOLD A.: 10-year research update review: The epidemiology of child and adolescent psychiatric disorders: I. Methods and public health burden. Journal of the American Academy of Child and Adolescent Psychiatry. 44 (10): 972-86, 2005.

27- ISMAIL A.A.A., HEGAZI H., LOTFI M., KAMEL A. and RAMDAN M.: The Prevalence and Risk Factors of Anxiety Disorders in an Egyptian Sample of School and 
Students at the Age of 12-18 Years. J. Psychiatry, 18: 316, 2015.

28- AL-MAMARI W.S., EMAM M.M., AL-FUTAISI A.M. and KAZEM A.M.: Comorbidity of Learning Disorders and Attention Deficit Hyperactivity Disorder in a Sample of Oman! Schoolchildren. Sultan Qaboos University Medical Journal, 15 (4): e528-e33, 2015.

29- PAULI-POTT U., NEIDHARD J., HEINZEL-GUTENBRUNNER M. and BECKER K.: On the link between attention deficit/hyperactivity disorder and obesity: Do comorbid oppositional defiant and conduct disorder matter? European child \& Adolescent Psychiatry, 23 (7): 5317, 2014.

30- LAZARUS B.D., DUPAUL G. and STONER G.: ADHD in the Schools: Assessment and Intervention Strategies. JSTOR, 2004

31- FLETCHER J.M., LYON G.R., FUCHS L.S. and BARNES M.A.: Learning disabilities: From identification to intervention: Guiiford. Press, pp. 25-27, 2006.

32- SOLANTO M.V.: Dopamine dysfunction in AD/HD: integrating clinical and basic neuroscience research. BehaviouraL Brain Research, 130 (1-2): 65-71, 2002.

33- RAO P.A. and LANDA R.J.: Association between severity of behavioral phenotype and comorbid attention deficit hyperactivity disorder symptoms in children with autism spectrum disorders, Autism: The international journal of Research and Practice, 18 (3): 272-80, 2014.

34- XIA W., SHEN L. and ZHANG J.: Comorbid anxiety and depression in school-aged children with attention deficit hyperactivity disorder (ADHD) and selfreported symptoms of ADHD, anxiety, and depression among parents of school-aged children with and without ADHD. Shanghai J. Archives of Psychiatry, 27 (6): 356-67, 2015.

35- ZORLU A., UNLU G., CAKALOZ B., ZENCIR M., BUBER A. and ISILDAR Y.: The prevalence and comorbidity rates of ADHD among school-age children in Turkey. Journal of Attention Disorders, 10870547155 77991, 2015.

36- MORADI A., KHABAZ K.M., AGAH T., JAVAHER F.A., REZVAN B., HAERI K.Z., et al.: The prevalence of attention deficit hyperactivity disorder (ADHD) among school children of Nishaboor-Iran during 2006, 2008.

37- PHEULA G.F., ROHDE L.A. and SCHMITZ M.: Are family variables associated with ADHD, inattentive type? A case-control study in schools. European child \& adolescent psychiatry, 20 (3): 137-45, 2011.

38- NAFI O.A. and SHAHEEN A.M.: Prevalence of attention deficit hyperactive disorder (ADHD) in school children in Al-Qaser district Jordan. Jordan Medical Journal, 45 (1): 128-38, 2011.

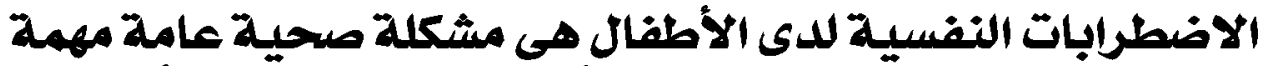

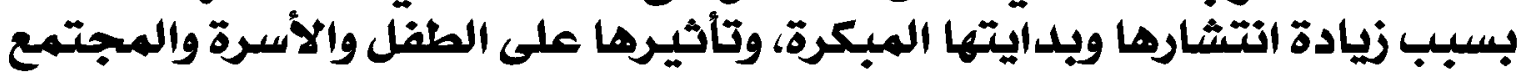

تم تصنيف اضطراب فرط النشاط نقص الانتباه كاضطراب فى النمو، وعلى الرغم من أنى أن بعض الخبراء النقاء يعتبرون أنه مرض اضطراب

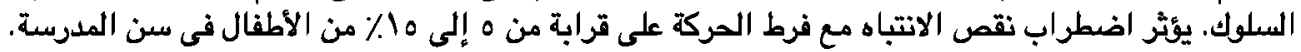

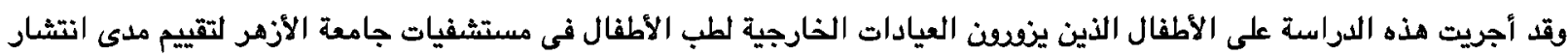

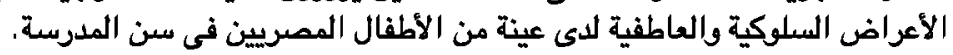

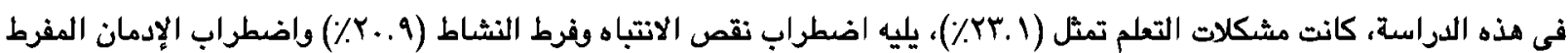

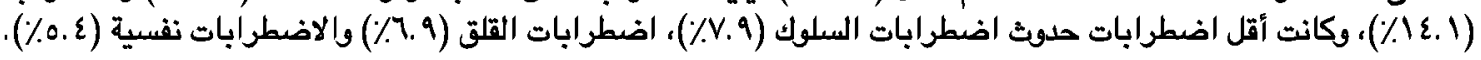

أظهر اضطراب نقص الانتباه مع فرط النشاط وجود علاقة إيجابية مع اضطرابات السلوك، ومشكلة التعلم، اضطرابات نفسية، واضطرابات

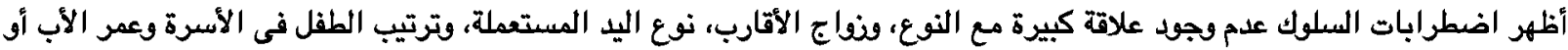
الطفل. على العكس أظهر عمر الأم علاقة عكسية هم اضطير العراب السلوك.

أظهرت مشكلة التعلم أنه لا علاقة كبيرة مع اليد المستخدمة، وترتيب الطفل فى الأسرة وعمر الطفل. ومع ذلالك، الذكورة، كانت مرتبطة نواج الأقارب بشكل كبير مع مشكلة التعلم. أظهر سن الأميرة الته الأب فى علاقة عكسية مع مشكلة التعلم.

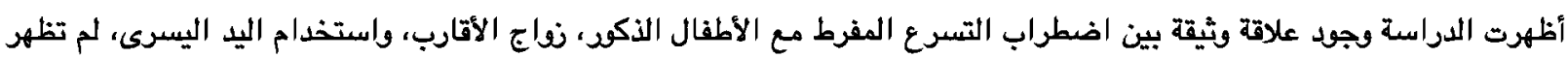

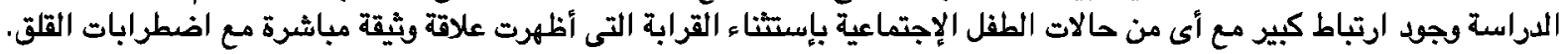

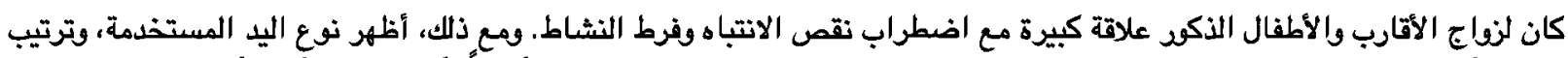

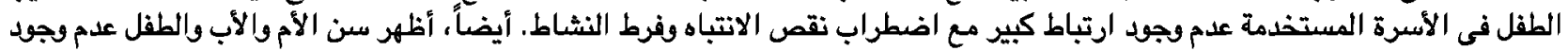
ارتباط كبير مع اضطراب نقص الانتباه وفرط النشاط.

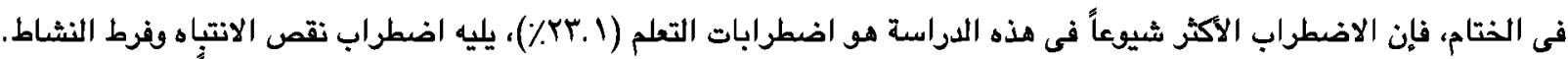

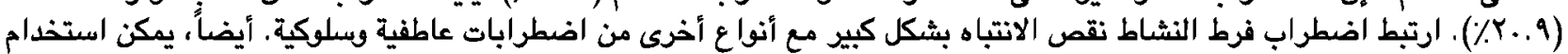

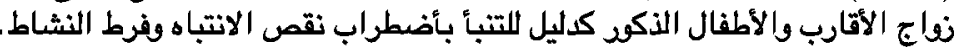

